\title{
MOTIVASI PEMAIN KLUB FAMILY FC PALEMBANG TERHADAP KOMPETISI SEPAK BOLA PADA MASA COVID-19
}

\section{MOTIVATION OF FAMILY FC PALEMBANG CLUB PLAYERS TO FOOTBALL COMPETITION DURING COVID-19}

\author{
Muhammad Imam Khalfari, Bayu Iswana, Bambang Hermansah \\ Fakultas Keguruan dan Ilmu Pendidikan, Universitas PGRI Palembang \\ Kontak Penulis: imamkhalfari13@gmail.com
}

\begin{abstract}
ABSTRAK
Penelitian ini bertujuan untuk mengetahui Motivasi pemain klub Family Fc Palembang terhadap Kompetisi Sepak bola pada Masa Covid-19. Metode yang digunakan penelitian ini adalah metode deskriptif kualitatif objek dalam penelitian ini berjumlah 25 pemain dan sampel 20 pemain,, Teknik dalam pengumpulan data penelitian data penelitian ini adalah menggunakan angket. Sedangkan Teknik analisis data yang digunaka adalah Teknik analisis data deskriptif. Hasil penelitian penelitian menunjukan bahwa : (1) hasil motivasi instrinsik adalah sebanyak $13,67 \%$ atau 3 orang karena faktor bakat, 20,7\% atau 5 orang karena faktor prestasi, 18,95\% atau 5 orang karena faktor pengetahuan, 26,76\% atau 7 orang karena faktor kesejahteraan, dan 19,92\% atau 5 orang karena hobi. (2) hasil motivasi ekstrinsik adalah sebanyak 24,43\% atau 6 orang karena faktor lingkungan, $13,7 \%$ atau 3 orang karena faktor pelatih, $25,11 \%$ atau 7 orang karena faktor orangtua, 13,24\% atau orang karena faktor sarana prasarana, dan 23,52\% atau 6 orang karena faktor teman. (3) hasil motivasi dari kedua faktor adalah 64,88\% atau sebanyak 16 orang menyatakan Ya termotivasi ditinjau dari kedua faktor, sedangkan sisanya 35,51\% atau 9 orang pemain menyatakan belum termotivasi dari kedua faktor tersebut.
\end{abstract}

Kata kunci: motivasi; kompetisi; Sepak bola

ABSTRACT

This study aims to determine the motivation of the Palembang Family Fc club players towards the Football Competition during the Covid-19 Period. The method used in this study is a qualitative descriptive method. The object in this study was 25 players and a sample of 20 players. The technique for collecting research data was using a questionnaire. While the data analysis technique used is descriptive data analysis technique. The results of the research showed that: (1) the results of intrinsic motivation were $13.67 \%$ or 3 people due to talent, $20.7 \%$ or 5 people due to achievement, $18.95 \%$ or 5 people due to knowledge, $26.76 \%$ or 7 people because of welfare factors, and $19.92 \%$ or 5 people because of hobbies. (2) the results of extrinsic motivation are as many as $24.43 \%$ or 6 people due to environmental factors, $13.7 \%$ or 3 people due to trainer factors, $25.11 \%$ or 7 people due to parental factors, $13.24 \%$ or people due to facilities infrastructure, and $23.52 \%$ or 6 people because of the friend factor. (3) the results of the motivation of the two factors were $64.88 \%$ or as many as 16 people stated that they were motivated from both factors, while the remaining $35.51 \%$ or 9 players stated that they were not motivated from these two factors.

Keywords: motivation; competition; football 


\section{PENDAHULUAN}

Olahraga adalah segala kegiatan yang sistematis untuk mendorong, membina, serta mengembangkan potensi jasmani, rohani, dan sosial. Olahraga memberikan kesempatan yang sangat ideal untuk menyalurkan tenaga dengan tujuan mencapai hidup yang sehat. Selain itu olahraga merupakan salah satu sarana yang efektif dalam membentuk karakter seseorang karna banyak nilai-nilai yang baik terkandung didalamnya seperti jujur, saling menghargai, berjiwa besar dan spotifitas (Wiarto, 2013) menjelaskan "Olahraga bukan hanya dilakukan oleh kalangan tertentu saja, olahraga bukan hanya milik kalangan tertentu saja, namun kegiatan olahraga telah menembus ke berbagai tingkatan usia maupun tingkatan kehidupan sosial dalam masyarakat di berbagai Negara". Banyak macam-macam olahraga yang ada didunia, salah satunya adalah olahraga Sepak bola.

Olahraga Sepak bola adalah salah satu olahraga yang paling banyak digemari. Saat globalisasi didengungkan, Sepak bola sudah sejak jauh hari menyebar ke seluruh belahan dunia, tak ada yang mampu menyatukan dunia selain Sepak bola (Firzani, 2010).

Motivasi adalah suatu daya dorong seseorang untuk melakukan sesuatu, baik yang timbul dari dirinya sendiri maupun yang timbul karena dorongan dari luar atau orang lain. Motivasi adalah daya penggerak yang telah menjadi aktif. Motif menjadi aktif pada saat-saat tertentu bila kebutuhan untuk mencapai tujuan sangat dirasakan atau dihayati (Husdarta, 2011).

Di awal tahun 2020, dunia digemparkan dengan merebaknya virus baru yaitu corona virus jenis baru (SARS-CoV-2) dan penyakitnya disebut Corona virus disease 2019 (COVID-19) (Yuliana, 2020). Diketahui, asal mula virus ini berasal dari Wuhan, Tiongkok (Kannan et al., 2020). Ditemukan pada akhir Desember tahun 2019 Masa-masa itu kemudian membuat klub Sepak bola mengambil tindakan cepat untuk menghentikan kompetisi. Klub Sepak bola mengikuti anjuran pemerintah untuk menunda kompetisi sampai masa pandemi benar-benar berakhir. Jika status darurat bencana dicabut, makakompetisi siap kembali bergulir.

Berdasarkan hasil observasi di klub Family Fc Palembang. Peneliti melihat masih kurangnya antusias pemain dalam sesi latihan dikarenakan masa pandemi berkepanjangan yang membuat kompetisi Sepak bola dihentikan, pemain merasa jenuh jika terus berlatih tanpa adanya kompetisi, hal ini dikhawatirkan akan memberikan dampak yang buruk bagi prestasi atlet. Tetapi untuk sekarang kompetisi sudah mulai bergulir di daerah-daerah termasuk juga di kota Palembang. Maka dari itu pentingnya untuk melihat seberapa besar motivasi pemain terhadap kompetisi Sepak bola pada masa covid-19, apakah pemain menjadi termotivasi untuk mengikuti kompetisi atau pemain menjadi malas untuk berkompetisi lagi.

\section{METODE PENELITIAN}

Penelitian ini menggunakan deskriptif kualitatif karena data yang akan di dapat dari penelitian ini berupa kuesioner. Jenis metode yang akan digunakan adalah metode survey. Menurut (Sugiyono, 2017) metode survey yang digunakan untuk mendapatkan data dari tempat tertentu yang ilmiah, tetapi penelitian melakukan perlakuan dalam pengumpulan data, misalnya dengan mengedarkan kuesioner, tes, wawancara terstruktur, dan sebagainya. 
Objek dalam penelitian ini adalah pemain Kub Family Fc Palembang yang terdiri dari 25 pemain. Sedangkan informasi dipilih berdasarkan karakteristik kesesuaian dengan data yang diperlukan yakni, pelatih, dan pemain. Informasi tersebut ditentukan dan ditetapkan pada jumlah yang dibutuhkan, melainkan berdasarkan fungsi dan peran informasi sesuai batas penelitian. Kategori subjek penelitian informan dalam penelitian ini adalah mereka yang terlibat langsung yaitu pemain Klub Family Fc Palembang.

Dalam penyusunan instrumen ini peneliti menggunakan angket. Angket yang digunakan dalam penyusunan instrumen adalah angket skala Guttman. Skala Guttman skala pengukuran dengan tipe ini akan didapat jawaban yang tegas, yaitu ya-tidak, benar-salah, pernah-tidak, positif-negative, dan lain- lain. Penelitian yang sebenarnya, mengukur motivasi pemain klub family fc palembang terhadap kompetisi Sepak bola pada masa covid-19 menggunakan skala guttman jawaban setiap item instrumen yang menggunakan skala guttman mempunyai gradasi dari sangat langsung pada pernyataan Ya (1) dan Tidak (2).

\section{HASIL PENELITIAN}

Pengujian validitas instrument dilakukan dengan SPSS 16 terhadap uji coba pertanyaan sebanyak 40 soal. Pengujian validitas di dasarkan pada jika rhitung> rtabel. Penentuan rtabel di dapat dari taraf signifikasi 0,05\% dengan $\mathrm{DF}=\mathrm{N}-1$ (20-1) yaitu 19. Maka rtabel diperoleh 0,433. Berdasarkan hasil jawaban yang telah di uji, maka di dapat sebanyak 29 soal dinyatakan valid, dan 11 soal dinyatakan tidak valid.

1. Deskripsi Variabel Berdasarkan Faktor Intrinsik

Faktor intrinsik dari variabel motivasi di dapat dari seluruh jawaban faktor intrinsik. Hasil analisis sebaran angket untuk mengetahui besarnya motivasi pemain klub Family Fc Palembang terhadap kompetisi Sepak bola pada masa covid-19 ditinjau dari aspek intrinsik berdasarkan data yang diperoleh di lapangan dan setelah di analisis menggunakan rumus di atas, dapat dilihat pada tabel di bawah ini:

Tabel 1.Persentase Faktor Instrinsik

\begin{tabular}{lcc}
\hline \multicolumn{1}{c}{ Kriteria } & Persen & Frekuensi \\
\hline Bakat & 13,67 & 3 \\
\hline Prestasi & 20,7 & 5 \\
\hline Pengetahuan & 18,95 & 5 \\
\hline Kesejahteraan & 26,76 & 7 \\
\hline Hobi & 19,92 & 5 \\
\hline Jumlah & 100 & 25 \\
\hline
\end{tabular}

(Sumber : Dokumentasi Peneliti)

Disimpulkan bahwa objek dalam penelitian ini sebanyak 25 pemain. Pemain yang termotivasi terhadap kompetisi Sepak bola pada masa covid-19 karena faktor intrinsik adalah sebanyak $13,67 \%$ atau 3 orang karena faktor bakat, 20,7\% atau 5 orang karena faktor prestasi, 18,95\% atau 5 orang karena faktor pengetahuan, 26,76\% atau 7 orang Karena faktor 
kesejahteraan, dan 19,92\% atau 5 orang karena faktor hobi. Jadi faktor kesejahteraan sangat berpengaruh bagi motivasi intrinsik pemain karena pemain menginginkan kesejahteraan yang membuat pemain mendapatkan masa depan yang cerah sementara faktor prestasi, pengetahuan, dan hobi juga mempengaruhi faktor motivasi intrinsik pemain karena ketiga faktor tersebut saling bersangkutan, faktor bakat juga mempengaruhi motivasi pemain tetapi bakat merupakan potensi yang dimiliki oleh seseorang sebagai bawaan sejak lahir.

2. Deskripsi Variabel Berdasarkan Faktor Ekstrinsik

Faktor ekstrinsik dari variabel motivasi didapat dari seluruh jawaban aspek ekstrinsik. Hasil analisis sebaran angket untuk mengetahui besarnya motivasi pemain klub Family Fc Palembang terhadap kompetisi Sepak bola pada masa covid-19 ditinjau dari aspek ekstrinsik berdasarkan data yang diperoleh di lapangan dan setelah di analisis menggunakan rumus di atas, dapat dilihat pada tabel di bawah ini:

\begin{tabular}{lcc}
\multicolumn{2}{c}{ Tabel 2.Persentase Faktor Ekstrinsik } \\
\hline \multicolumn{1}{c}{ Kriteria } & Persen & Frekuensi \\
\hline Lingkungan & 24,43 & 6 \\
\hline Pelatih & 13,7 & 3 \\
\hline Orang Tua & 25,11 & 6 \\
\hline Sarana Prasarana & 13,24 & 3 \\
\hline Teman & 23,52 & 6 \\
\hline Jumlah & 100 & 25 \\
\hline
\end{tabular}

(Sumber Dokumentasi Peneliti)

Disimpulkan bahwa objek dalam penelitian ini sebanyak 25 pemain. Pemain yang termotivasi pada kompetisi Sepak bola pada masa covid-19 dari faktor ekstrinsik adalah sebanyak 24,43\% atau 6 orang karena faktor lingkungan, 13,7\% atau 3 orang karena faktor pelatih, $25,11 \%$ atau 7 orang karena faktor orang tua, 13,24\% atau 3 orang karena faktor sarana prasarana, dan $23,52 \%$ atau 6 orang karena faktor teman. Jadi faktor orang tua sangat mempengaruhi faktor ekstrinsik pemain karena motivasi yang di berikan orang tua merupakan kebutuhan atau keadaan yang ada dalam pribadi seseorang yang mendorong individu melakukan kegiatan-kegiatan tertentu untuk mencapai tujuan yang di inginkan, sementara faktor lingkungan dan faktor teman sangat berpengaruh bagi motivasi ekstrinsik pemain karena saling berkaitan, sementara faktor pelatih dan sarana prasarana juga mempengaruhi motivasi ektrinsik pemain karena jika ingin mencapai tujuan pemain harus melakukan latihan yang tekun dan di perlukan lapangan untuk melakukan latihan tersebut.

3. Hasil Analisis Data

Untuk mengetahui seberapa besar persentase pemain yang termotivasi terhadap kompetisi Sepak bola pada masa covid-19 ditinjau dari dua faktor intrinsik dan ekstrinsik berdasarkan data yang diperoleh di lapangan dan setelah di analisis menggunakan rumus di bawah, dapat dilihat pada tabel di bawah ini: 
Tabel 3. Persentase Motivasi Pemain

\begin{tabular}{lcc}
\hline Keriteria & Persentase & Frekuensi \\
\hline Ya & 64,88 & 16 \\
\hline Tidak & 35,51 & 9 \\
\hline Jumlah & 100 & 25 \\
\hline
\end{tabular}

(Sumber : Dokumentasi Peneliti)

Disimpulkan bahwa pemain yang termotivasi terhadap kompetisi pada masa covid-19 adalah $64,88 \%$ atau sebanyak 16 orang mengatakan Ya termotivasi ditinjau dari kedua faktor, karena dari bakat disalurkan ke hobi dan mendapatkan pengetahuan tentang teknik-teknik tentang Sepak bola dan mendapatkan prestasi dibidang olahraga Sepak bola sehingga pemain ingin mendapatkan masa depan dan kesejahteraan di olahraga Sepak bola. Sedangkan sisanya $35,51 \%$ atau 9 orang pemain menyatakan belum termotivasi dari kedua faktor tersebut karena alasan bermain Sepak bola dan ikut kompetisi Sepak bola hanya ingin menjaga kebugaran tubuh, hobi dan alasan lainnya.

\section{PEMBAHASAN}

Motivasi pada dasarnya adalah kondisi mental yang mendorong dilakukanya suatu tindakan dan memberikan kekuatan yang mengarah pada pencapaian kebutuhan memberi kepuasan atau mengurangi ketidak seimbangan (Hadjarati \& Haryanto, 2020). Dorongan yang baik tentu saja di butuhkan oleh sesorang dalam menjalani sebuah aktivitas. Khususnya aktivitas untuk mencapai prestasi seorang atlet (Haryanto et al., 2021). Atlet merupakan pelaku olahraga yang berkecimpung dalam olahraga tertentu. Untuk meningkatkan prestasi seorang atlet membutuhkan dorongan atau motivasi dalam mengikuti pelatihan, salah satu seperti Sepak bola.

Motivasi merupakan salah satu faktor yang cukup penting dalam meningkatkan prestasi seorang atlet (Henjilito, 2017). Dikarenakan dorongan yang kuat dari dalam maupun luar akan menjadi penyemangat seseorang dalam mengikuti latihan, dengan meningkatnya semangat dan motivasi tersebut maka seseorang akan melakukan latihan dengan sungguh-sungguh, dengan demikian kemampuan altlet tersebut juga akan meningkat.

Berdasarkan temuan hasil penelitian pada pemain Family Fc Palembang dalam rangka memunculkan motivasi pemain terhadap kompetisi Sepak bola pada masa covid-19, diperoleh hasil bahwa pemain yang termotivasi terhadap kompetisi Sepak bola pada masa covid-19 dari faktor intrinsik adalah sebanyak 13,67\% atau 3 orang karena faktor bakat, 20,7\% atau 5 orang karena faktor prestasi, $18,95 \%$ atau 5 orang karena faktor pengetahuan, $26,76 \%$ atau 7 orang karena faktor kesejahteraan, dan 19,92\% karena faktor hobi, dan pemain yang termotivasi terhadap kompetisi Sepak bola pada masa covid-19 dari faktor ekstrinsik adalah sebanyak $24,43 \%$ atau 6 orang karena faktor lingkungan, $13,7 \%$ atau 3 orang karena faktor pelatih, 25,11\% atau 6 orang karena faktor orang tua, $13,24 \%$ atau 3 orang karena faktor sarana prasarana, dan $23,52 \%$ karena faktor teman. Sedangkan pemain yang termotivasi terhadap kompetisi Sepak bola pada masa covid-19 dari kedua faktor adalah $64,88 \%$ atau sebanyak 16 orang menyatakan Ya 
termotivasi ditinjau dari kedua faktor, sedangkan sisanya 35,51\% atau 9 orang pemain menyatakan belum termotivasi dari kedua faktor tersebut

Berdasarkan hasil tersebut, lebih dari $50 \%$ jawaban menyatakan termotivasi terhadap kompetisi Sepak bola pada masa covid-19 karena alasan yang muncul dari faktor intrinsik dan faktor ekstrinsik. Hal tersebut menandakan bahwa dalam bermain Sepak bola ada banyak aspek yang mempengaruhi keinginan pemain sehingga termotivasi terhadap kompetisi Sepak bola pada masa covid-19

Sepak bola adalah jenis permainan bola besar yang sangat menyenangkan (Jumhana \& Agustan, 2016), dan memiliki banyak manfaat di dalamnya. Selain bermanfaat untuk kebugaran, Sepak bola juga memiliki banyak manfaat lainya, misalnya membina mental, bahkan sampai pada memunculkan prestasi dalam Sepak bola (Mardhika \& Dimyati, 2015), sehingga wajar jika pemain begitu termotivasi terhadap kompetisi Sepak bola walaupun di masa pandemi covid-19. Tetapi banyak hal yang harus di perhatikan klub Sepak bola untuk menjaga para pemain agar tidak berdampak buruk bagi pemain selama masa pandemi ini agar mematuhi protokol kesehatan seperti mencuci tangan sebelum dan sesudah latihan, memakai masker, dan menjaga jarak di luar maupun di dalam lapangan agar terhindar dari penyebaran virus covid-19.

\section{KESIMPULAN}

Motivasi intrinsik pemain klub Family Fc Palembang terhadap kompetisi Sepak bola pada masa covid-19 yang paling mempengaruhi motivasi intrinsik pemain adalah indikator kesejahteraan karena para pemain ingin ikut berpartisipasi terhadap kompetisi Sepak bola pada masa covid-19 karena ingin mempunyai masa depan yang bagus lewat kompetisi Sepak bola pemain mendapatkan prestasi dan menjadikan Sepak bola menjadi hobi yang bisa mendapatkan penghasilan.

Motivasi ekstrinsik pemain klub Family Fc Palembang terhadap kompetisi Sepak bola pada masa covid-19 yang paling mempengaruhi indikator orang tua karena orang tua adalah orang yang paling mengerti dan memahami apa yang ingin dilakukan dari anaknya dan mendukung semua kegiatan yang ingin dilakukan baik secara kebutuhan materi maupun kebutuhan psikologi.

\section{REFERENSI}

Firzani, H. (2010). Segalanya tentang Sepak bola. Erlangga.

Hadjarati, H., \& Haryanto, A. I. (2020). Motivasi Untuk Hasil Pembelajaran Senam Lantai. Multilateral Jurnal Pendidikan Jasmani Dan Olahraga. https://doi.org/10.20527/multilateral.v19i2.8646

Haryanto, A. I., Gani, A. A., Ramadan, G., Samin, G., Fataha, I., \& Kadir, S. S. (2021). Shooting Athlete Mental Training. JUARA: Jurnal Olahraga, 6(1). https://doi.org/https://doi.org/10.33222/juara.v6i1.1188

Henjilito, R. (2017). Pengaruh Daya Ledak Otot Tungkai, Kecepatan Reaksi dan Motivasi terhadap Kecepatan Lari Jarak Pendek 100 Meter pada Atlet PPLP Provinsi Riau. Journal Sport Area. https://doi.org/10.25299/sportarea.2017.vol2(1).595

Husdarta, H. J. S. (2011). Manajemen Pendidikan Jasmani. Alfabeta. 
Jumhana, \& Agustan, B. (2016). Pengaruh Model Directinstruction terhadap Teknik Dasar Dribbling dalam Permainan Sepak Bola. JUARA: Jurnal Olahraga, 1(1), 46-50. https://doi.org/https://doi.org/10.33222/juara.v1i1.57

Kannan, S., Shaik Syed Ali, P., Sheeza, A., \& Hemalatha, K. (2020). COVID-19 (Novel Coronavirus 2019) - recent trends. European Review for Medical and Pharmacological Sciences, 24(4). https://doi.org/10.26355/eurrev_202002_20378

Mardhika, R., \& Dimyati, D. (2015). Pengaruh Latihan Mental Dan Keyakinan Diri Terhadap Keberhasilan Tendangan Penalti Pemain Sepak Bola. Jurnal Keolahragaan. https://doi.org/10.21831/jk.v3i1.4973

Sugiyono. (2017). Metode Penelitian Kuantitatif, Kualitatif dan R\&D. Alfabeta.

Wiarto, G. (2013). Fisiologi dan Olahraga. Graha Ilmu.

Yuliana. (2020). Olahraga yang Aman di Masa Pandemi COVID-19 untuk Meningkatkan Imunitas Tubuh. Jurnal Bali Membangun Bali, 1(2). https://doi.org/10.51172/jbmb.v1i2.112 